\title{
The influence of psychology on Russian didactic terminology (early 18th century - first half of 20th century)
}

\author{
Nina V. Bordovskaia ${ }^{\mathrm{a}^{*}}$, Elena A. Koshkina ${ }^{\mathrm{b}}$ \\ a Department of Psychology, Saint Petersburg State University, St. Petersburg, Russia \\ ${ }^{\mathrm{b}}$ Department of Pedagogy, Northern (Arctic) Federal University, Arkhangelsk, Russia \\ *Corresponding author. E-mail: nina52@mail.ru
}

\begin{abstract}
Success in the development of cross-disciplinary connections between psychology and pedagogy in today's Russia depends on many factors, including understanding the historical traditions of theoretical comprehension of educational innovations. To identify the specific influence of psychology on didactic terminology from the early 18 th century through the first half of the 20th century. The study was designed based on historiographic, diachronic, and synchronic methods, and context and content analysis of 129 texts (105 words with general usage frequency of 81,397 units were analyzed). It was found reasonable to split the development of psychological-didactic terminology into two stages: the instrumental stage (early 18th century - first half of 19th century) and the reference stage (second half of 19th century - first half of 20th century). The first stage was found to be characterized by psychological terms performing predominantly an instrumental function, that is, describing psychological factors that affect the effectiveness of training. The second stage featured the growing significance of psychological knowledge, not only in solving educational tasks, but also in explaining didactic patterns. During the first stage of development of psychological-didactic terminology, teachers frequently used the psychological terms "teaching", "ability", and "diligence"; during the second stage - "teaching", "senses", and "development". Statistical methods were used to prove stable conceptual and terminological connections between psychology and pedagogy.
\end{abstract}

Keywords: psychological-didactic terminology and its structural organization, stages and tendencies of its development in Russia

\section{Introduction}

The history of science has been a topic of intense discussion since the mid-20th century. Several models of the genesis of scientific knowledge have been established: the cumulative model (E. Mach, P. Duhem, H. Spencer, and others), the scientific revolution model (A. Koyré), the evolutionary model (S.E. Toulmin, D.T. 
Campbell), the paradigm model (T. Kuhn), falsificationism (K. Popper, I. Lakatos), etc. However, no matter which model is selected to describe the development of science, its terminology is one of the main indicators of change, since the evolution of scientific knowledge manifests itself through transformation of terminology and of the internal and external structural bonds that form its framework.

Psychology and pedagogy have developed over centuries, taking different forms and relationships which, in turn, affected how effectiveness in training and education processes was explained and described. In the 19th century, K.D. Ushinsky, in his work "Chekovek kak predmet vospitaniya. Opyt pedagogicheskoi antropologii" ["The person as the subject of education. Experience of pedagogical anthropology"] (1868-1869) noted the leading role of psychology solving pedagogical problems and tasks. P.F. Kapterev (1877) viewed the pedagogical process as "an expression of the internal independent action of the person" and as the development of abilities. Our contemporaries continue to expand our understanding of the nature and origins of psychological and pedagogical knowledge. Elaborating on the subject of psychopedagogy, L.M. Friedman (1997) emphasizes that in the field of educational psychology, issues concerning the development and formation of a student's personality are usually analyzed and resolved without consideration of the educational system that led to them and to the educational methods involved. E. Stones, in his book Psychopedagogy (1987), states that actual teaching practice is the most reliable and important way to test the psychological theory upon which general principles of teaching are based. Many similar opinions, suggestions, and wishes are detailed not only by psychologists, but by teachers as well (Bordovskaia, 2008, p. 86). But the major interconnection between pedagogy and psychology is their relation to human sciences and to problems of teaching, education, and training (Ananyev, 1968, p. 31).

For our study of Russian psychological and didactic terminology development, we selected the 18th century through the first half of the 20th century. The beginning of this period was when the Russian educational system began to take shape and the first works appeared that directly elaborated on didactic problems. The end of the selected period was when Russian didactics and educational psychology emerged as independent fields of science, when both psychologists and teachers became increasingly interested in scientific achievements and their active use in theoretical understanding of educational innovations and in the search for ways to optimize the teaching process.

Analysis of historical and psychological literature (Martsinkovskaya, 2004; Minkova, 2010; Mazilov, 2014) and of historical and pedagogical literature (Dzhurinsky, 2010; Kicheva, 2011; Ryzhov, 2012; Kornetov, Lukatsky., 2013; Bobryshov, 2013) has shown that the development of psychopedagogical knowledge often starts from the delimitation of the subject domain of research, with a focus on a specific conceptual and categorical framework, based on the subject field of pedagogical and psychological science, and also from the emergence of new terms. This is a challenging process and can be a long one. Moreover, the status of any scientific structure that is a cross-discipline of psychology and pedagogy is defined not by declarative statements, but by accumulation of a certain amount of scientific information and empirical data, the relevance and objectivity of which are acknowledged by both psychologists and teachers. At the same time, the name of a newly 
established scientific branch is of no small importance: the name defines the science, and its significance is sometimes associated with history and scientific tradition, while it impacts the structural organization of psychological and pedagogical terminology.

All this has contributed to the relevance of studying the historical context in which Russian psychopedagogical terminology was formed. The purpose of the study was to provide evidence for historical stages that reflect specific usages of didactic and psychological terminology in pedagogical texts during this historical period.

\section{Method}

The goal was achieved in a three-stage procedure (Bordovskaia \& Koshkina, 2014). During the first stage, we refined our understanding of the historical process of conceptual and terminological relationships between psychology and pedagogy, and identified the logical and lexicological bases for development of psychopedagogical terminology.

The second stage was devoted to the selection of methods to solve the following tasks:

- obtaining factual data on the status of psychological-didactic terminology during the selected historical period (18th century to 20th century) source study method;

- identification of the relationship between the contents of pedagogical texts and quantification of didactic and psychological terms and distribution thereof across sense-groups - content analysis;

- identification of the causes and nature of historical changes in psychological-didactic terminology - diachronic method;

- identification of specific usages of pedagogical terms in texts of various genres during the same chronological period - synchronic method;

- determination of the content of didactic and psychological concepts used in the pedagogical text when such content is not directly elaborated - context analysis.

During the third stage, quantitative data manipulation methods (analytical grouping, correlation analysis) were used to specify objective indicators of the state of psychological-didactic terminology and changes during the selected historical period (usage frequency, number of text sources where the term can be found), as well as to identify general trends.

The sample texts comprised those that allowed us not only to determine the current level of development of educational theory and practice, but also to evaluate the individual contributions of public figures, scientists, and teachers to this process. The concepts and terms used in the texts depend extensively on individual authors' theoretical standpoints and preferences, as well as on the context in which such terms are used. Particular attention was paid to specialized educational literature on pedagogy and didactics that concisely and clearly reflects the level of development of learning theory captured in special concepts and terms, among other ways. 
The texts were included in the sample based on two criteria: authenticity and informativity. Historical authenticity means that a text was created within the historical period being analyzed. Linguistic authenticity requires that texts translated into Russian from other languages (Greek, Latin, English, French, German, etc.) be excluded from the sample. Stylistic and structural authenticity means that the texts have not been shortened or subjected to later stylistic changes or revisions other than by the author. The most significant criterion for inclusion of a text in the study is its informational capacity. The general requirement for all texts was that they should directly or indirectly address organizational and practical issues of the teaching process for different population categories and age groups. The sample mainly included works by authors who significantly influenced Russian pedagogical science and practice.

Texts were selected in accordance with nonprobabilistic partial sampling (Titscher et al., 2009, p. 37). This type of sampling is used when it is impossible to accurately estimate the exact number of texts created during the given historical period and to determine how the sampled texts were distributed across intermediate stages to determine the dynamics of their quantitative characteristics.

\section{Theoretical foundations of historical and qualimetric research}

Our understanding, study, and analysis of psychological-pedagogical terminology in the historical and qualimetric context was supported by the following scientific foundations:

1. The establishment and development of the conceptual-terminological system of any science is rather closely related to the process of establishment and development of scientific knowledge as such (Buniyatov, 1988, p. 42). In our case, this is psychology and pedagogy, or, to be more precise, educational psychology and didactics in Russia.

2. Since the process of a person's learning and development in educational practice is dialectical, the definition of concepts is continuously being adjusted, and therefore, the verbal form is changing as well (Reznikov, 1958, p. 9).

3. Development of psychopedagogical knowledge is greatly influenced by cultural and historical conditions, processes that take place within the language (emergence of new words that more accurately convey the interpretation of reality, attempts to improve linguistic designation, etc.) and particular features of scientific communication (expansion of scientific communication channels, popularization of scientific knowledge, etc.).

4. Psychological and pedagogical terms are characterized by polysemy and synonymy; a strong tendency for scientists to create new terms; contextdependency, which dictates the use of linguistic means, as well as the high validity of their linguistic units (Vinogradov, 1953, p. 6). When a new psychological or pedagogical term appears, it may have no strict definition; its definition grows gradually and may change, as a new psychological theory or pedagogical concept appears. 
In view of the above, we consider the historical process of interaction between psychology and pedagogy in the conceptual and terminological context in Russia as a change in the role of a certain set of terms in the course of elaboration of psychological and pedagogical issues during a given historical period of development of didactics, educational psychology, and the Russian educational system.

The goal set for the research called for the use of periodization as a special type of systematization of historical facts. Periodization allows us to represent the historical process of psychopedagogical knowledge development as a regular and sequential change of periods of time with common and specific characteristics, and qualitative changes of this knowledge over time. Use of periodization requires establishing a criterion for objective assessment, comparison, and classification of objects, processes, and phenomena, and their development within certain time frames. Periodization of the development of psychological-pedagogical terminology was based on quantitative characteristics of terms used as names for learning, as well as those that stand for psychological processes, attributes, and states of personality, which determine how effective educational processes are. Content analysis and analytical grouping, used to characterize the usage of psychological terms during the analyzed period, allowed us to use such quantitative indicators as frequency and consistency of term usage. Frequency of a term's usage reflects its significance in conveying the main idea of a text and is expressed as an absolute number of times that this term appears in an individual text, in a group of texts, or in the entire sample of texts. Usage frequency is not a random index; it is one of the principal formal and logical properties of the conceptual framework of science. It is used to assess the analyticity of a text, i.e., the author's attention to the clarification and explanation of particular concepts. Usage frequency depends on the amount of vocabulary in the text and the total number of terms therein. In this study, term usage frequency was determined as a percentage of the total number of instances a term is used within the corresponding group of terms.

A term usage consistency index allows us to objectively assess how consistently lexical units are used over a prolonged period of time. It is an important indicator for texts where psychological-didactic issues are explained indirectly, and when the frequency of usage of a term across a number of sources is irregular. Term usage consistency was assessed using a consistency coefficient, calculated as follows:

$$
k=\frac{n}{N},
$$

where $\mathrm{n}$ is the number of texts in which the analyzed word occurs, and $\mathrm{N}$ is the total number of sampled texts. If $k \geq 0,8$ term usage is considered consistent, $0,5 \leq k<0,8$ indicates average consistency, $0,2 \leq k<0,5$ indicates power consistency, and $0 \leq k<0,2$ means that usage of the term is inconsistent.

Based on the selected criterion, two stages of psychological-didactic terminology development were identified (an instrumental stage and a reference stage). These periods were used as the time frame for assessment of how the main psychological and didactic terms and their relationships changed, and what the nature of such changes was. 


\section{Results}

The first stage (instrumental stage) covers the period from the 18th century to the mid-19th century. More than 80 pedagogical texts were used to study the development of psychological and didactic terminology over this period. These texts included works by I.T. Pososhkov, F. Prokopovich, V.N. Tatishchev, M.V. Lomonosov, I.I. Betskoy, F.I. Jankovich de Mirievo, A. Obodovsky, and others. The sample of terms consisted of 93 units (without synonyms) with a total usage frequency of 3,850 units; it included words that designate pedagogical and psychological processes, traits and states of personality that influence the effectiveness of education. The distribution of the sample across groups of terms is shown in Figure 1.

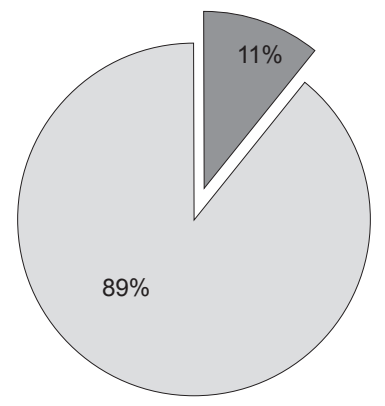

$\square$ Terms-names of pedagogical processes

Figure 1. Distribution of sampled psychological and pedagogical terms across groups (early 18th century - first half of 19th century)

Analysis showed a low frequency of usage for psychological terms, less than $11 \%$ in the distribution of terms (see Figure 2).

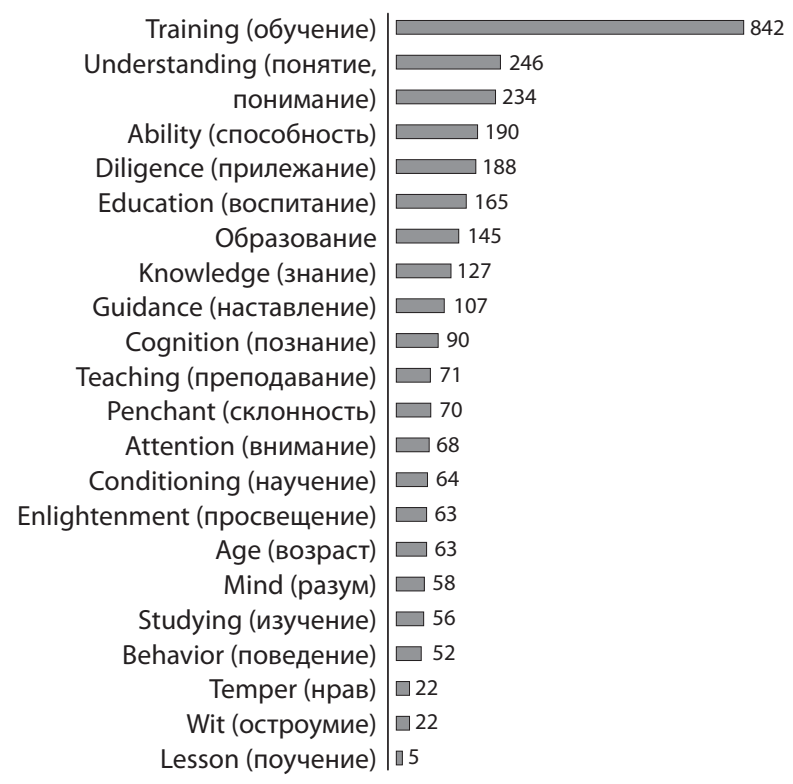

Figure 2. Frequency of the use of psychological and pedagogical terms (the beginning of the 18th to the first half of the 19th centuries) 
The results show that during the studied period, the psychological foundations of the targeted process of transferring and acquiring educational information were outside the focus of scientific interest, which was due to the level of psychological knowledge in general and to the significant role that organizational aspects of the teaching process played in the Russian educational system. This fact is also supported by the consistency of usage of terms in pedagogical texts of the 18th - the first half of the 19th centuries (see Table 1).

Table 1. Consistency of usage indexes of psychological and pedagogical terms (early 18th century - first half of 19th century)

\begin{tabular}{lcccc}
\hline & $\begin{array}{c}\text { High usage } \\
\text { consistency }\end{array}$ & $\begin{array}{c}\text { Average usage } \\
\text { consistency }\end{array}$ & $\begin{array}{c}\text { Poor usage } \\
\text { consistency }\end{array}$ & $\begin{array}{c}\text { Inconsistent } \\
\text { usage }\end{array}$ \\
\hline Psychological terms & & $1.3 \%$ & $18 \%$ & $81.7 \%$ \\
Terms - pedagogical processes & $11 \%$ & & $78 \%$ & $11 \%$ \\
\hline
\end{tabular}

We compared the frequency of usage of lexical units designating psychological phenomena and of terms for such processes as «training» («обучение»), «education» («воспитание»), and «teaching» («преподавание»); this allowed us to determine the dynamics of active usage of terms during this stage of development of psycho-pedagogical knowledge (see Figure 3).

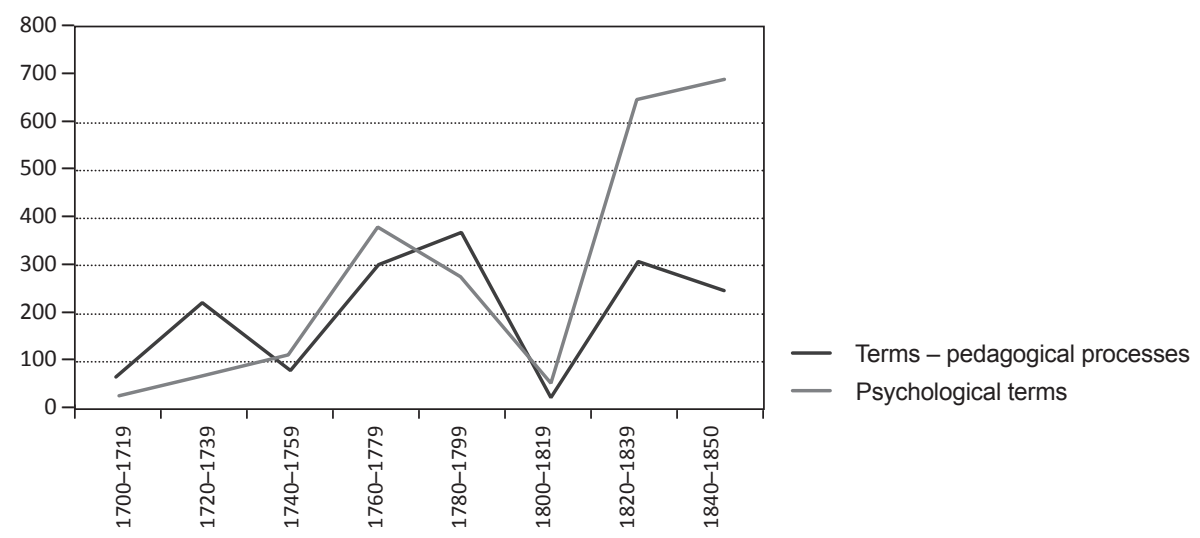

Figure 3. Dynamics of the use activity of psichological and pedagogical terms (the beginning of XVIII — the first of the XIX centuries)

The linear relationship in the change of usage frequency of psychological and pedagogical terms was determined through correlation analysis, using Pearson's coefficient. Statistical analysis of quantitative data yielded a correlation coefficient of.64, which indicates a moderate linear relationship between frequency of usage of psychological and pedagogical terms. Therefore, the interaction of didactics and psychology at a conceptual and terminological level is typical even for the early stages of development of the former. It should be noted that such interaction has 
become more frequent by the end of the analyzed period, as shown by increased usage of psychological terms in pedagogical texts.

One of the most important characteristics of the level of development of psychological-pedagogical terminology is the meaning of lexical units used as terms. Based on context analysis, the terms most commonly used in the sources studied were identified.

It was found that the term "ability" («способность») (usage frequency of 232 units, $k=.53$ ) was mostly used to describe students' personality traits that influence the learning process. For teachers, ability was considered as an attribute of personality that ensures good professional results ("teaching ability" [«способность к преподаванию»], "lecturing ability” [«способность к чтению лекций»], etc.). The term "behavior” («поведение») (usage frequency of 52 units, $k=.2$ ) was used to describe subjects' moral characteristics in their activities that influence the effectiveness of the educational process. For students, mostly negative behavioral characteristics that require rectification were noted, while for teachers, the emphasis was on positive characteristics that were exemplary and that served as an important condition for employment by an educational institution or by a family for home schooling. The term "diligence" («прилежание») (usage frequency of 190 units, $k=.32$ ) was used to describe the attitude of both a teacher and a student towards their duties in the course of the training/learning process. In the 19th century this characteristic was taken into account when evaluating a student's results during the academic year, when transferring a student to the next grade, and when a student was graduating (in the last case, diligence was noted on the diploma). For teachers, diligence as a positive personality trait was important for career development and remuneration by the educational institution.

Data obtained from context analysis showed that the terms "knowledge" («знание») and "understanding” («понятие») are characterized by polysemy and synonymy. These terms were used as follows:

- to describe the results of assimilating the surrounding reality and certain fields of human activity (e.g., science) $-24 \%$ and $6 \%$, respectively (e.g., "knowledge of Latin"” («знание латинского языка»), "general understanding” («понятие общее»);

- to characterize the results of the learning process - $23 \%$ and $18 \%$, respectively ("perfect knowledge” («знание совершенное»), "sufficient understanding” («понятие достаточное»);

- to describe intellectual abilities, professional and learning skills $-4 \%$ and $20 \%$, respectively ("knowledge of reading and writing” [«знание чтения и письма»], "quick understanding" [«понятие быстрое»]).

It should be noted that as early as the analyzed period "knowledge (cognition)" («знание» [«познание»]) was considered the main criterion for selection of teachers.

1 Latin was the official language of Russian scientific texts in the first part of the $18^{\text {th }}$ century. 
During the analyzed period, many teachers believed that successful learning depended also on the student's inclination to learn, for which the term "propensity" («склонность») was used (usage frequency of 142 units, $k=.3$ ). This concept reflected primarily a certain set of natural intellectual qualities that are manifest in the course of learning ("natural propensity” [«природная склонность»], "propensity for science” [«склонность к наукам»], "propensity to read books” [«склонность к чтению книг»]).

Pedagogical texts of the analyzed period also featured the term "age" («возраст») (usage frequency of 63 units, $k=.2$ ) and terms within the conceptual-terminological field of "age" that stand for different periods of human life that are considered more favorable for training and education: "childhood” («возраст малый»), “adolescence” («возраст отроческий»), “уоuth” («юношество»). It should be noted that awareness of the age of the person in the educational process was reflected in the way that educational institutions organized their enrollment of students and formation of study groups.

Pedagogical texts of the 18th century to the first half of the 19th century used such psychological terms as "attention" («внимание») (usage frequency of 70 units, $k=.27$ ), "memory” («память») (usage frequency of 64 units, $k=.22$ ), "intellect” («ум») (usage frequency of 67 units, $k=.1$ ), which reflected students' cognitive learning processes that ensured a good outcome.

In the first half of the 19th century, ideas of West European philosophy, pedagogy, and psychology started finding their way into Russian pedagogical theory and practice. Professional training of teachers for public schools and the necessity to factor a psychological component into this training become very important. The result was the emergence of the first textbooks on pedagogy that included psychological sections and psychological vocabulary. For example, one of the first Russian textbooks on didactics, Rukovodstvo $k$ didaktike, ili nauke prepodavaniya [Guidelines on didactics, or the science of teaching], by A.G. Obodovsky, used the term "mental strengths" («душевные силы»), which combined such concepts as “intellect” («ум»), “imagination” («воображение»), and "memory” («память») (Obodovsky, 1837). The author operated with such terms as "consciousness" («сознание») and “development” («развитие»). However, it should be noted that despite its importance, this Russian textbook was an adaptation of works by German pedagogue A.H. Niemeyer titled Principles of education and teaching (1796) and Fundamentals of pedagogy and didactics (1802), which were adjusted to Russian vocabulary. This certainly does not diminish the value of the psychologicaldidactic terminology that was known in Europe and was being introduced to Russian pedagogy.

The second stage of development of Russian psychological-pedagogical terminology covers the mid-19th century to the mid-20th century and is associated with a change in the role of psychological knowledge in development of pedagogical theory and educational practice.

Pedagogy no longer dealt exclusively with practical, organizational aspects of the educational process. Progressive pedagogues now began searching for theoretical grounds to explain the nature, including the psychological nature, of the educational process, its structural elements (purposes, ideas, methods, forms, means, etc.), as well as trends of further development in solving challenging problems of 
educational practice. This is the reason that teachers started closely monitoring achievements in the field of psychology.

One of the first Russian pedagogues to introduce the concept of "psychological foundations of pedagogy" was V.F. Odoevsky, in his article "Opyt o pedagogicheskikh sposobakh pri pervonachal'nom obrazovanii detei" ["Essay on pedagogical methods used during primary education of children"] (1845, p. 144). It was also he who introduced such terms as "psychological fact" («психологический факт»), "psychological phenomenon" («психологическое явление»), "psychological task" («психологическая задача»), “conscious” («сознательное»), "unconscious” («бессознательное»), "unconscious understanding" («бессознательное понятие»), "unconscious motivation” («бессознательное побуждение»), etc., to pedagogical texts.

During the second stage, 50 sources (articles, monographs, and manuals published from 1850 to 1959) were used to study the development of psychological-pedagogical terminology. Authors included P.P. Blonsky, M.I. Demkov, K.V. Elnitsky, B.P. Yesipov, N.K. Goncharov, A.B. Zalkind, P.F. Kapterev, V.F. Odoevsky, A.P. Pinkevich, N.I. Pirogov, M.M. Rubenstein, K.D. Ushinsky, and S.P. Shevyrev.

The sample consisted of 46 words and word combinations (excluding synonyms) that define pedagogical processes (education [«воспитание»], training [«обучение»], teaching [«преподавание»]); psychological terms (feeling [«ощущение»], perception [«восприятие»], memory [«память»], thought [«мышление»], imagination [«воображение»], personality [«личность»], etc.); age-specific stages of development considered more favorable for learning (childhood [«детство»], adolescence [«подростковый возраст»], youth [«юность»]). Total usage frequency of these terms amounted to 75,547 units. Distribution of the sampled terms across groups of terms is shown in Figure 4.

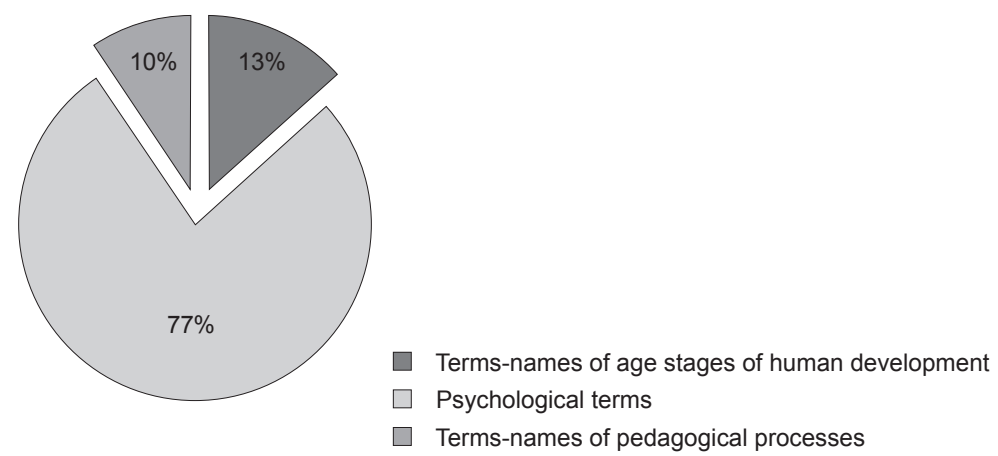

Figure 4. Distribution of sampled psychological and pedagogical terms across groups (second half of 19th century - first half of 20th century)

The figure demonstrates a significant increase in the usage frequency of psychological terms, which indicates their growing importance for the development of pedagogical science and description of its theoretical foundations, as well as for professional training of future teachers (see Figure 5). 


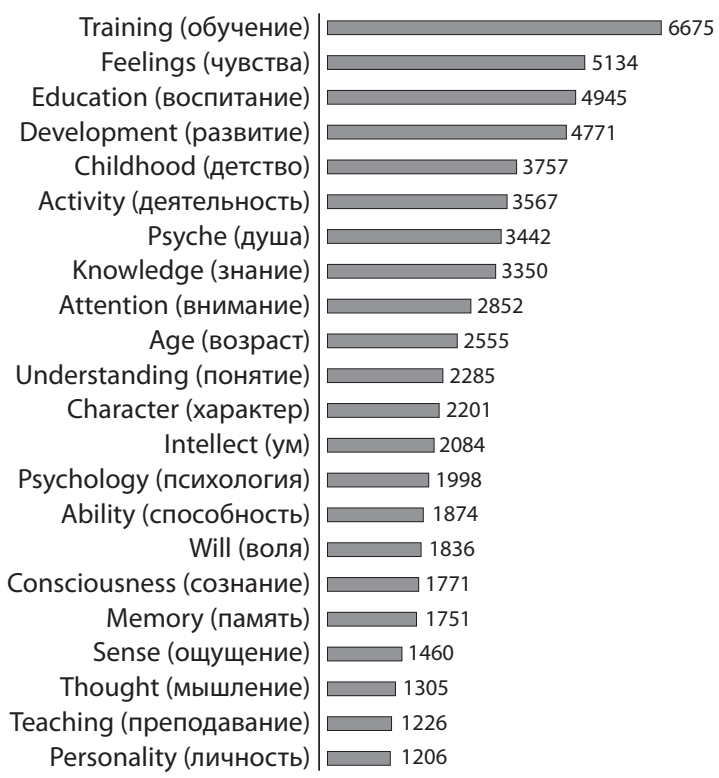

Figure 5. Use frequency of psychological and pedagogical terms (second half of 19th - first half of 20th centuries)

During the analyzed period, the coefficient of consistency increased greatly for psychological terms, which indicates some stabilization of their meanings and less introduction of novel concepts and terminology by individual authors - i.e., when a term is encountered in the works of only one author (see Table 2). This can be considered the most important indicator of an established vocabulary of educational psychology as a branch of psychological knowledge.

The usage of psychological and pedagogical terms during the analyzed period is graphically shown in Figure 6.

Statistical analysis of quantitative data for the groups "Terms - names of pedagogical processes" and "Terms of general psychology" yielded a correlation coefficient of -0.64 , which indicates a moderate inverse relationship between the frequency of usage of terms in these groups. The correlation coefficient for frequency

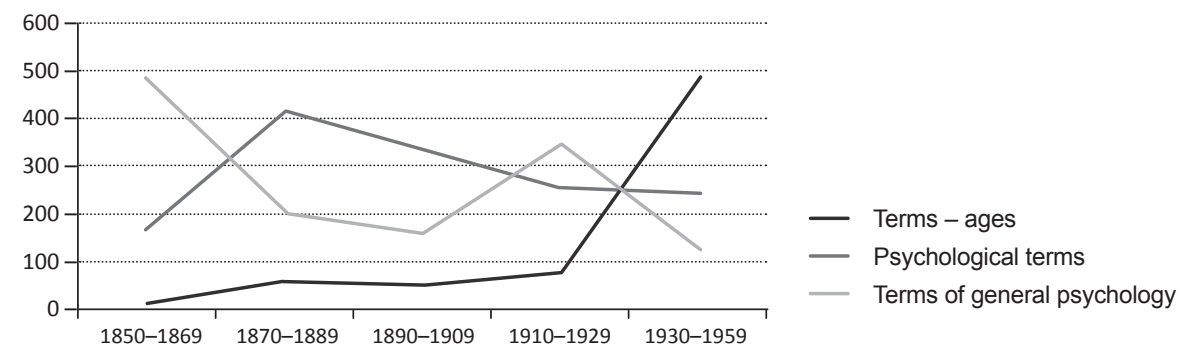

Figure 6. The usage of psychological and pedagogical terms (second half of 19th century - first half of 20th century) 
Table 2. Psychological and pedagogical terms usage consistency indicators (second half of 19th century - first half of 20th century)

\begin{tabular}{lcccc}
\hline & $\begin{array}{c}\text { High usage } \\
\text { consistency }\end{array}$ & $\begin{array}{c}\text { Average usage } \\
\text { consistency }\end{array}$ & $\begin{array}{c}\text { Poor usage } \\
\text { consistency }\end{array}$ & $\begin{array}{c}\text { Inconsistent } \\
\text { usage }\end{array}$ \\
\hline Terms - pedagogical processes & $80 \%$ & $20 \%$ & & \\
Terms - ages & $14 \%$ & $14 \%$ & $58 \%$ & $14 \%$ \\
Terms of general psychology & $15 \%$ & $53 \%$ & $26 \%$ & $6 \%$ \\
\hline
\end{tabular}

of usage of the groups "Terms - names of pedagogical processes" and "Terms names of age stages" was -.17 , which suggests a very weak inverse relationship. The correlation coefficient for the frequency of usage of terms in the groups "Terms of general psychology" and "Terms - names of age stages" was -.56, which also indicates a moderate inverse relationship between the frequency of usage of the terms in these two groups.

The quantitative data allow us to conclude that increased frequency of usage of pedagogical terms leads to decreased frequency of usage of general psychological terms and vice versa. This can be explained by the fact that terms for pedagogical processes are used more often when authors are mainly paying attention to organizational aspects of the learning process. When explaining the psychological grounds for personality development in the course of learning, the psychological group of terms is used to describe conditions that affect the effectiveness and productivity of that process.

Increased frequency of usage of terms for age periods can be explained by the intensive development of pedology and developmental psychology during this historical period and the attitude of teachers towards results obtained by scientists. In particular, K.D. Ushinsky believed that the main grounds for development of pedagogy are physiology, logic, and psychology, and his point of view very accurately reflected the tradition of using psychological knowledge to describe and explain the pedagogical process: "If pedagogy wishes to educate a person in all aspects, it first of all must learn about this person in all aspects" (Ushinsky, 1950, p. 23). A while later, another classic scholar of pedagogical science, P.F. Kapterev, in his fundamental work Pedagogicheskaya psikhologiya [Educational psychology] (1914), introduced the term "educational psychology" («педагогическая психология») for the scientific discipline "that connects pedagogy with psychology and leads from psychology to pedagogy" (Kapterev, 1914, p. iii). This work included data on general psychology necessary for the teacher, "presented mainly in terms of the development of mental processes and in connection with pedagogical conclusions"; data on the psychology of childhood and "further ages of education"; "studies of types of mental lives in general and types of individual mental processes in particular" (ibid., p. iv).

Thus, conceptual and terminological connections between pedagogy and psychology were originally formed in the context of organizational aspects and issues of productivity of the educational processes. 
From the second half of the 19th century to the first decade of the 20th century, teachers become more interested in age-specific issues of development during the school years. This was prompted by the development of experimental psychology and pedology and led to more active use of lexical units that fall into the conceptual and terminological field of "age" ("childhood" [«детский возраст»], "preschool age" [«дошкольный возраст»], "school age" [«школьный возраст»], etc.).

Manuals on pedagogy and didactics started to include clear definitions and classifications of pedagogical phenomena with the use of special lexical means adopted from psychology. For example, activities of a teacher associated with shaping of students' conceptual understanding was based on the knowledge of psychology behind the generation of mental images and ideas. Rukovodstvo $k$ prepodavaniyu obshcheobrazovatel'nykh predmetov [Guidelines on teaching of general subjects] characterized elements of thought as various representations of the human psyche and defines combinations of such elements through laws of the association of concepts (Vessel et al., 1874, p. 70). Specifics of students' thought and the distinctive features of development of learning processes were considered the foundation for the classification of teaching methods that gained popularity during this period, which implied that teaching methods are to be divided into an analytical one ("movement toward the concept") and a synthetic one ("movement from the concept") (Yurkevich, 1869, p. 253; Skvortsov, 1899, p. 32).

Significantly increased frequency of usage of the terms "feeling" («чувство») and "sense" («ощущение») indicates increasing attention of teachers to the use of visualization in the teaching process and to explanation of the mechanisms behind mastering of information using sensory organs. The use of visual teaching methods in educational practice during the studied period was based on knowledge of the physiology and psychology of feeling and sensation. I.V. Skvortsov notes: "Visualization technique is based on the unarguable psychological fact that concepts that form a foundation of our judgments and conclusions result from ideas; the correctness and clarity of ideas as such evidently depends on the completeness, accuracy, and clarity of the senses or, broadly speaking, on the accuracy and clarity of sensible observation. Therefore, no verbal description can be compared to actually observing an object" (Skvortsov, 1899, p. 62).

Thanks to the theoretical and experimental studies of Russian pedologists (A.P. Nechayev, V.M. Bekhterev, A.B. Zalkind, P.P. Blonsky, M.Y. Basov, L.S. Vygotsky, and others), new terms ("social development of a child" [«социальное развитие ребенка»], "social factor of child's development" [«социальный фактор развития ребенка»], "problem children” [«трудные дети»], "pedagogically neglected children” [«педагогически запущенные дети»], "socially neglected child" [«социально запущенный ребенок»]) were introduced to the psychological and didactic terminology. The term "zone of proximal development” («зона ближайшего развития,» introduced by L.S. Vygotsky into scientific vocabulary, later became one of the most important terms to explain the principle of developmental teaching and to understand the psychological grounds for selection of teaching content and methods in order to develop a student. 


\section{Conclusions}

Our results allow us to conclude that changes in the content and quantitative characteristics of the conceptual and terminological framework may provide a basis for the periodization of the development of science. The study showed that the analyzed periods when psychological and didactic terminology were rather consistently used in pedagogical texts (the early 18th century to the first half of the 19th century; the second half of the 19th century to the mid-20th century) confirm the opinions of scientists regarding a "turning point" in the development of Russian pedagogy and psychology, in the middle of the 19th century (Kapterev, Demkov, Dzhurinsky, Martsinkovskaya, Mazilov, etc.).

The development of Russian psychological and pedagogical terminology during the first stage (the early 18th century to the mid-19th century) was characterized by a predominantly instrumental function of psychological terms, which mainly consists in: designating psychological conditions that affect the effectiveness of educational processes; a direct relationship between quantitative characteristics of dynamics of usage of terms that are names of pedagogical processes and psychological terms; the use of psychological terms to describe the teacher's and the student's personal traits that contribute to or hinder the transfer and acquisition of information; describing mental attributes, phenomena, and processes that are important for organizational and practical aspects of the educational process; and describing the results of training.

The second stage (mid-19th century - mid-20th century) was characterized by the growing importance of psychological knowledge in solving educational tasks and explaining didactic patterns. These processes also affected the way psychological terms were used in pedagogical texts: the size of the vocabulary and the usage frequency increased, and an inverse relationship was identified between the use of pedagogical and general-psychological terms. The results of theoretical and experimental studies of distinctive features of mental processes in the course of learning, as well as the influence of age-specific development of students, were the most important factors in understanding the learning process and finding the best ways to organize it. Psychological terminology is used to promote new pedagogical ideas and to create new theories.

\section{Acknowledgements}

This article received financial support from the Russian Foundation for the $\mathrm{Hu}$ manities, project No. 16-06-00486.

\section{References}

Ananyev, B. G. (1968). Chelovek kak predmet poznaniya [The person as the subject of knowledge]. Leningrad: Izdatelstvo Leningradskogo universiteta.

Bobryshov, S. V. (2013). Istoriya pedagogiki kak pole metodologicheskikh determinant istorikopedagogicheskogo issledovaniya [History of pedagogy as a field of methodological determinants of historical and pedagogical research]. Istoriko-pedagogicheskii zhurnal [The Journal of History and Education], 2, 35-47. 
Bordovskaia, N. V. (2008). Ob integratsii psikhologicheskogo i pedagogicheskogo znaniya [About integration of psychological and pedagogical knowledge]. Innovatsii v obrazovanii [Innovations in Education], 1, 86-90.

Bordovskaia, N. V., \& Koshkina, E. A. (2014). Metodika izucheniya istorii razvitiya didakticheskoi terminologii [Methodology of studying the history of development of didactic terminology]. Pedagogika [Pedagogy], 10, 26-35.

Buniyatov, A. R. (1988). O sootnoshenii istoricheskogo i logicheskogo v razvitii nauki [On the ratio of the historical and logical in the development of science]. Frunze: Elm.

Dzhurinsky, A. N. (2010). Istoriya pedagogiki kak nauka i uchebnyi predmet: problemy, tendentsii, perspektivy [The history of pedagogy as a science and a subject: problems, tendencies, prospects]. Gumanitarnye nauki i obrazovanie [Humanities and Education], 4, 7-13.

Friedman, L. M. (1997). Psikhopedagogika obshchego obrazovaniya [Psychopedagogy in general education]. Moscow: Institut prakticheskoi psikhologii.

Kapterev, P. F. (1914). Pedagogicheskaya psikhologiya [Educational psychology]. St.Petersburg: Zemlya.

Kicheva, I. V. (2011). Transformatsii sovremennogo ponyatiino-terminologicheskogo apparata rossiiskoi pedagogiki [Transformations of the framework of modern conceptual terms in Russian pedagogy]. Pyatigorsk: Pyatigorsk State Linguistic University.

Kornetov, B. G., \& Lukatsy, M. A. (2013). Istoriya pedagogiki: teoreticheskoe vvedenie [History of pedagogy: Theoretical introduction]. Moscow: ASOU.

Martsinkovskaya, T. D. (2004). Istoriya psikhologii [History of psychology]. Moscow: Academia.

Mazilov, V. A. (2014). Metodologicheskie problemy istorii psikhologii [Methodological problems of the history of psychology]. Privolzhskii nauchnyi vestnik [Privolzhye Scientific Bulletin], 11-2(39), 31-35.

Minkova, G. S. (2010). Osobennosti stanovleniya psikhologii razvitiya v Rossii vtoroi poloviny XIX - pervoi treti XX veka [Features of the formation of developmental psychology in Russia of the second half of the 19th -first third of the 20th century]. Metodologiya $i$ istoriya psikhologii [Methodology and History of Psychology], 5(2), 40-48.

Obodovsky, A. (1837). Rukovodstvo $k$ didaktike, ili nauke prepodavaniya, sostavlennoe po Nimeieru [Guidelines on didactics, or the science of teaching according to Niemeyer]. St.Petersburg: Tipografiya Konrada Vingebera.

Odoevsky, V. F. (1845). Opyt o pedagogicheskikh sposobakh pri pervonachal'nom obrazovanii detei [Essay on pedagogical methods used during primary education of children]. Otechestvennye zapiski [Domsetic Notes], 12, 130-146.

Reznikov, L. O. (1958). Ponyatie i slovo [Concept and word]. Leningrad: Leningrad State University.

Ryzhov, A. N. (2012). Genezis pedagogicheskikh ponyatii $v$ Rossii $v$ XI-XX $v v$ [Genesis of pedagogical concepts in Russia in the 19th - 20th centuries]. Moscow: Moscow Pedagogical State University Press.

Skvortsov, I. V (1899). Zapiski po pedagogike. Chast'vtoraya. Obshchaya didaktika [Notes on pedagogy. Part II. General didactics]. Saint Petersburg: Tipografiya A.L. Trunova i Ko.

Stones, E. (1984). Psychopedagogy. Psychological theory and the practice of teaching. Moscow: Pedagogika.

Ushinsky, K. D. (1950). Chelovek kak predmet vospitaniya. Opyt pedagogicheskoi antropologii [The person as the subject of education. Experience of pedagogical anthropology]. In K.D. Ushinsky. Sobranie sochinenii [Collected works]. Vol. 1. Moscow-Leningrad.

Vessel, N. H. (Ed.) (1874). Rukovodstvo k prepodavaniyu obshcheobrazovatelnykh predmetov, vkhodyashchikh $v$ kurs: domashnego obucheniya, narodnykh, gorodskikh i rea’nykh uchilishch, 
muzhskikh i zhenskikh gimnazii i progimnazii, zhenskikh institutov, dukhovnykh uchilishch $i$ seminarii i vsekh drugikh obshcheobrazovatelnykh zavedenii izdavaemoe pod redaktsii N.Kh. Vesselya. T.II. Obshchaya chast. Vtoroi otdel [Guidelines on teaching general subjects in the curriculum: home schooling, state, municipal secondary schools, boys' and girls' gymnasiums and pro-gymnasiums, women's institutes, religious schools and seminaries, and all other general education institutions. Volume II. General part. Second section]. Saint Petersburg: Tipografiya V.S. Balasheva.

Vinogradov, V. V. (1953). Osnovnye tipy leksicheskogo znacheniya slova [The main types of lexical meaning of a word]. Voprosy yazykoznaniya [Issues in Linguistics], 5, 3-29.

Vygotsky, L. S. (1934). Myshlenie i rech [Thought and speech]. Moscow, Leningrad: Gosudarstvennoe sotsialno-ekonomicheskoe izdatelstvo.

Yurkevich, P. (1869). Kurs obshchei pedagogiki s prilozheniyami [Course of general pedagogy with appendices]. Moscow: Tipografiya Gracheva.

Original manuscript received December 01, 2015

Revised manuscript accepted June 30, 2016

First published online March 31, 2017 